\author{
Contents list available at Multidisciplinary Journal website \\ Multidisciplinary Journal \\ Journal homepage: https://jurnal.unej.ac.id/index.php/multijournal
}

\title{
Pengaruh Konsentrasi dan Time Efek Ekstrak Batang Serai Wangi (Cymbopogon nardus) dalam Bentuk Spray sebagai Bioinsektisida Nyamuk Aedes aegypti
}

\section{Effect of Concentration and Letal Time Extract from Lemongrass Stem (Cymbopogon nardus) on spray as Bioinsecticide Aedes aegypti}

\author{
Khoirul Anam ${ }^{1, *}$, Isa Ma'rufi ${ }^{2}$, Dwi Wahyuni ${ }^{3}$ \\ ${ }^{1}$ Pascasarjana Universitas Jember Jl. Kalimantan No. 37 Kampus Tegal Boto Jember \\ ${ }^{2}$ Pascasarjana Universitas Jember Jl. Kalimantan No. 37 Kampus Tegal Boto Jember \\ ${ }^{3}$ Fakultas MIPA Universitas Jember Jl. Kalimantan No. 37 Kampus Tegal Boto Jember (TNR 9) \\ Email*: cunam.212@gmail.com
}

\begin{abstract}
Dengue Hemorrhagic Fever is an insect tropic disease that always threatens the Indonesian population every year and becomes an outbreak in several regencies/cities in Indonesia after the changing seasons. The Aedes aegypti mosquito vector control effort has been carried out both physically with the PSN program or chemically using synthetic insecticides that can be directed against both adult mosquitoes and larvae. Fragrant citronella extract based on previous research contains many alkaloid compounds that can inhibit cholinesterase enzymes such as synthetic organophosphate class insecticides. The purpose of this study was to analyze the effect of concentration and time effect of citronella extract (Cymbopogon nardus) in the form of a spray as a natural bioinsecticide to control the Aedes aegypti mosquito. This research belongs to a pure research design (true experiment) with factorial design. The research unit has 3 units plus 1 unit as a control using 25 mosquitoes for each research unit. Data analysis in this study used the Repeated Measure GLM and Probit analysis. The results showed that the concentration and time effect of citronella extract had a test result of $0.0001<0.005$. The conclusion of the study was the effect of concentration and time effect of citronella extract on the death of Aedes aegypti mosquitoes. The results of the probit analysis found that the value of LT50 was 27.49 minutes after the intervention and LC50 was 3,198 ppm.
\end{abstract}

Keywords: Frarant of citronella, spray, Aedes aegypti

ABSTRAK. Demam Berdarah Dengue merupakan penyakit tropic inseksi yang selalu mengancam penduduk Indonesia setiap tahun dan menjadi KLB dibeberapa kabupaten / kota di Indonesia setaip pergantian musim. Usaha pengendalian vektor nyamuk Aedes aegypti sudah dilakukan baik secara fisik dengan program PSN atau secara kimia dengan menggunakan insektisida sintetik yang dapat ditujukan terhadap nyamuk dewasa maupun larva. Ekstrak batang serai wangi berdasarkan penelitian sebelumnya banyak mengandung senyawa alkaloid yang mampu menghambat enzim cholinesterase seperti insektisida golongan oeganophosphate sintetik. Tujuan penelitian ini adalah menganalisis pengaruh konsentrasi ndan time efek ekstrak serai wangi (Cymbopogon nardus) dalam bentuk spray sebagai bioinsektisida alami untuk mengendalikan nyamuk Aedes aegypti. Penelitian ini termasuk kedalam rancangan penelitian murni (true experiment) dengan rancangan factorial. Unit penelitian ini ada 3 unit ditambah 1 unit sebagai kontrol dengan menggunakan 25 ekor nyamuk untuk setiap unit penelitian. Analisis data pada penelitian ini menggunakan uji statistik Repeated Measure GLM dan analisis Probit. Hasil penelitian menunjukkan bahwa kjonsentrasi dan time efek ekstrak batang serai wangi memiliki hasil uji $0.0001<0.005$. Kesimpulan penelitian didapatkan pengaruh konsentrasi dan time efek ekstrak serai wangi terhadap kematian nyamuk Aedes aegypti. Hasil analisis Probit didapatkan bahwa nilai LT50 sebesar 27,49 menit setelah intervensi dan LC50 adalah sebesar $3.198 \mathrm{ppm}$

Kata Kunci: Ekstrak Serai Wangi, Spray, Aedes aegypti

\section{Pendahuluan}

WHO selaku organisasi kesehatan dunia telah memberikan rekomendasi dalam penggunaan insektisida untuk mengendalikan nyamuk Aedes aegypti sebagai vektor penyakit DBD (demam berdarah dengue) yaitu dengan menggunakan malathionpada nyamuk stadium dewasa dan pada stadium larva dengan menggunakan temephos 1\% atau lebih sering disebut Abate. Penelitian yang dilakukan oleh Heny Prasetyowati dkk (2016) terhadap insektisida 
golongan organophosphate di wilayah DKI Jakarta didapatkan hasil bahwa telah terjadi resistensi nyamuk Aedes aegypti terhadap insektisida malathion dan temephos $1 \%$ di wilayah DKI Jakarta, sehingga perlu dicari insektisida yang baru serta teruji keefektifannya terhadap kematian nyamuk Aedes aegypti [1].

Insektisida organophosphate adalah insektisida sintetik dengan waktu paruh yang panjang sehingga perlu diperhatikan dampak residu dari penggunaan insektisida organophosphate tersebut. Dampak penggunaan insektisida sintetik dalam jangka waktu yang lama selain resistensi serangga adalah terjadinya gangguan kesehatan manusia dan kesehatan lingkungan [2]

Resistensi yang terjadi akibat penggunanaan insektisida sintetik golongan organophosphate secara terus menerus dalam pengendalian vektor nyamuk Aedes aegypti dapat dilihat dari gambaran data yang dirilis oleh Kemenkes RI pada tahun 2010 dan 2015yang menunjukan terjadi KLB demam berdarah dengue di beberapa kabupaten/kota di beberpa propinsi di Indonesia. Data yang dirilis oleh Balitbang Kemenkes RI per Februari 2016 disebutkan telah terjadi fenomena KLB DBD di 7 propinsi dengan 9 kabupaten dan 2 kota di Indonesia, sedangkan pada bulan Maret 2016 telah bertambah 4 propinsi dan 6 kabupaten menetapkan status KLB DBD termasuk Kabupaten Situbondo di Jawa TimurData kasus DBD untuk wilayah Jawa Timur periode Januari - Maret 2016 telah terjadi sebanyak 858 kasus dan 27 diantaranya meninggal dunia, sedangkan jumlah kasus DBD di Jawa Timur pada tahun 2015 sebanyak 19.942 kasus DBD dan 277 meninggal dunia. Berdasarkan jumlah kasus DBD di Jawa Timur periode Januari - Maret 2016, Kabupaten Jember menempati posisi kedua terbanyak setelah Kabupaten Jombang yaitu sebanyak 170 kasus yang dilaporkan dan 3 korban meninggal.[3]

Serai wangi (Cymbopogon nardus L) yang mengandung senyawa alkaloid seperti geraniol dan sitronelol yang memiliki kemampuan sebagai insektisida dengan bekerja layaknya pestisida golongan organophosphate yang bersifat kontak dengan menghambat enzim cholinesterase sehingga akan terjadi kontraksi otot secara terus menerus. Kontraksi otot yang terjadi secara terus menerus termasuk otot pernapasan serangga, maka akan terjadi gangguan pernapasan yang akan menyebabkan terjadinya kematian nyamuk karena kekurangan oksigen.[4]

\section{Bahan dan Metode}

Jenis penelitian eksperimen adalah suatu penelitian dengan melakukan percobaan murni (true experiment) yang dimaksudkan untuk mengetahui gejala atau pengaruh yang akan timbul akibat dari suatu perlakuan atau intervensi tertentu pada eksperimen tersebut. [6] Penelitian ini menggunakan menggunakan 3 unit penelitian ditambah 1 unit sebagai control dengan 3 kali pengulangan untuk setiap unit. Tempat penelitian dilakukan di Laboratorium Entomologi Lembaga Penyakit Tropis Universitas Airlangga Surabaya pada bulan Nopember 2018 sampai dengan Januari 2019 [6].
Variabel terikat pada penelitian ini adalah jumlah kematian nyamuk Aedes aegypti setelah mendapat intervensi berupa penyemprotan atau spray ekstrak batang serai wangi yang sudah ditentukan konsentrasinya yaitu 1000 ppm, 5000 ppm dan 10.000 ppm dan dilakukan observasi secara time efek pada periode waktu yang telah ditentukan yaitu observasi menit ke-15, menit ke-30, menit ke-60, menit ke-120 dan menit ke-240 setelah intervensi. Variabel kendali adalah variabel yang berpotensi mengganggu hubungan variabel terikat dan variabel bebas namun dapat dikendalikan sehingga tidak mempengaruhi hasil hubungan antar variabel dalam penelitian. Suhu, kelembaban dan angin dalam penelitian ini merupakan variabel kendali. Analisis data pada penelitian ini menggunakan uji statistik Repeated Measure GLM dan analisis Probit.

\section{Hasil dan Pembahasan}

Tabel 3.1 Jumlah rata-rata kematian nyamuk pada pemberian ekstrak batang serai wangi.

Rata-rata Jumlah Kematian Nyamuk (\%)

\begin{tabular}{ccccccc}
\hline No & $\begin{array}{c}\text { Ekstrak } \\
(\mathbf{P p m})\end{array}$ & $\begin{array}{c}\text { Menit } \\
\text { ke-15 }\end{array}$ & $\begin{array}{c}\text { Menit } \\
\text { ke-30 }\end{array}$ & $\begin{array}{c}\text { Menit } \\
\text { ke-60 }\end{array}$ & $\begin{array}{c}\text { Menit } \\
\text { ke- } \\
\mathbf{1 2 0}\end{array}$ & $\begin{array}{c}\text { Menit } \\
\text { ke- } \\
\mathbf{2 4 0}\end{array}$ \\
\hline 1 & Kontrol & 0 & 0 & 0 & 0 & 0 \\
\hline 2 & 1000 & 0,0 & 20,0 & 65,3 & 73,3 & 76,0 \\
\hline 3 & 5000 & 13,3 & 48,0 & 89,3 & 93,3 & 93,3 \\
\hline 4 & 10.000 & 54,7 & 96,0 & 100,0 & 100,0 & 100,0
\end{tabular}

Sumber : Data Primer Terolah, 2019

Hasil uji statistik yang sudah dilakukan menggunakan aplikasi SPSS dengan uji statistik Repeated Measure GLM (General Linier Model) didapatkan bahwa pengaruh konsentrasi dan time efek ekstrak serai wangi (Cymbopogon nardus) dalam bentuk spray sebagai bioinsektisida alami nyamuk Aedes aegypti sebesar 0.0001 . Nilai tingkat signifikansi 0.0001 lebih kecil dari pada nilai $\mathrm{T}$ Tabel yang sudah ditentukan yaitu 0.005 sehingga $\mathrm{H} 0$ ditolak dan Ha diterima yang menyatakan bahwa konsentrasi dan time efek ekstrak batang serai wangi (Cymbopogon nardus) memiliki pengaruh sebagai bioinsektisida alami terhadap kematian nyamuk Aedes aegypti. Berdasarkan hasil uji analisis probit nilai LT $_{50}$ ekstrak batang serai wangi sebesar 27,49 menit setelah intervensi dan $\mathrm{LC}_{50}$ ekstrak batang serai wangi adalah sebesar 3.198 ppm. Hasil Pos Hoc LSD didapatkan bahwa terdapat pengaruh yang signifikan untuk setiap kepekatan konsentrasi terhadap kematian nyamuk Aedes aegypti sebagai sampel, sedangkan faktor time efek menit ke-15 sampai menit ke-60 berbeda secara signifikan dan menginjak meneit ke-60 samapi menit ke240 setelah intervensi tidak berbeda secara signifikan. 


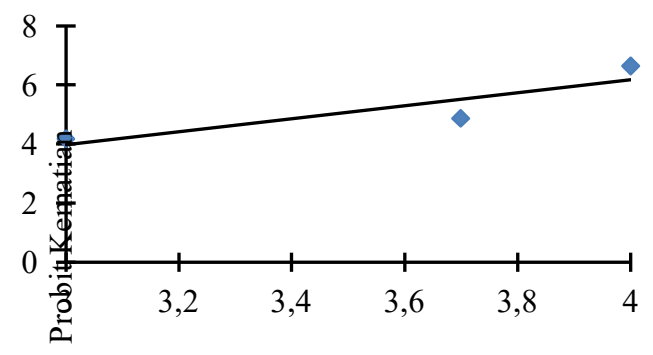

[Log Konsentrasi]

Grafik probit analisis $\mathrm{LC}_{50}$ ekstrak batang serai wangi

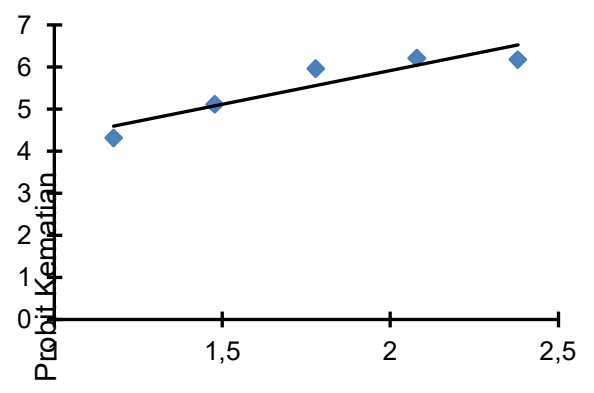

[Log Waktu]

Grafik probit LT ekstrak batang serai wangi

Hasil observasi terhadap jumlah kematian nyamuk

Aedes aegypti setelah intervensi menggunakan ekstrak batang serai wangi dalam bentuk spray sesuai dengan kepekatan konsentrasi ekstrak dan durasi time effect sebagai bioinsektisida alami nyamuk Aedes aegypty pada penelitian ini memberikan hasil yang cukup menggembirakan. Insektisida nabati adalah insektisida yang berasal dari tumbuhan yang mengandung bahan aktif seperti alkaloid (geraniol, sitronellol, rotenon, dll), saponin, tannin, flavonoid. Serai wangi (Cymbopogon nardus) yang mengandung bahan aktif geraniol dan stronellol sebagai alkaloid utama telah banyak dipergunakan sebagai larvasida yang memiliki cara kerja menghambat kerja enzim cholinesterase [7].

Kandungan senyawa metabolit sekunder pada ekstrak kasar dengan menggunakan pelarut etanol dan fraksi etil asetat dari batang serai wangi (Cymbopogon nardus) adalah flavonoid, fenolik dan terpenoid, sedangkan dengan menggunakan fraksi etil asetat hanya mengandung senyawa steroid [9]. Penelitian lain menyatakan bahwa dalam mengurangi larva demam berdarah maka dilakukan dengan pemanfaatan ekstrak serai wangi. Dari penelitian tersebut didapatkan semua konsentrasi pada kelompok perlakuan memiliki hasil perbedaan secara bermakna dengan kelompok kontrol dengan nilai $\mathrm{p}<0,05$. Jumlah kematian larva tertinggi pada konsentrasi $2 \%$ yaitu $38 \%$ kematian larva dan terendah pada konsentrasi $0,05 \%$ dan konsentrasi $0,1 \%$ yaitu $8 \%$ kematian larva. Disimpulkan bahwa semua konsentrasi pada kelompok perlakuan efektif sebagai larvasida apabila dibandingkan dengan kontrol dengan nilai $\mathrm{p}<0,05$ [8].

Berdasarkan beberapa penelitian yang dilakukan oleh peneliti sebelumnya tentang kandungan dan kemampuan ekstrak serai wangi yang sudah ada diatas didapatkan bahwa ekstrak batang serai wangi merupakan bahan yang efektif untuk mengendalikan nyamuk dan larva dari Aedes aegypty. Hal tersebut terlihat dari Repeated Measure GLM didapatkan hasil bahwa terdapat pengaruh yang signifikan antara kepekatan konsentrasi ekstrak dan time effect ekstrak batang serai wangi terhadap kematian sampel nyamuk Aedes aegypti. Pada uji lanjutan dengan Pos Hoc LSD untuk mengetahui perbedaan pengaruh variabel dependen berupa kepekatan konsentrasi dan time effect terhadap kematian sampel nyamuk didapatkan hasil bahwa pada semua variabel dependen memiliki pengaruh yang signifikan terhadap jeumlah kematian sampel nyamuk kecuali pada konsntrasi 1000 ppm dan 5000 ppm pada waktu observasi menit ke-15 dan pada konsentrasi 5000 ppm dan konsntrasi 10.000 ppm menit ke 120 setelah intervensi.

Hasil uji analisis probit menggunakan program excell untuk mengetahui nilai LT50 dan LC50 ekstrak batang serai wangi didapatkan hasil LT50 sebesar 27,49 menit setelah intervensi dan LC50 sebesar 3.198 ppm. Nilai LT50 ini memberikan arti bahwa kemampuan membunuh 50 $\%$ populasi sampel nyamuk dari ekstrak batang serai wangi dalam bentuk spray ini membutuhkan waktu selama 27,49 menit setelah intervensi. Sedangkan kepekatan konsentrasi ekstrak batang serai wangi yang mampu membunuh $50 \%$ dari populasi sampel nyamuk adalah sebesar 3.198 ppm dalam bentuk spray. Besarnya nilai waktu dan konsentrasi ini terjadi karena adanya proses toksokinetik dan toksodinamik dari racun atau zat racun terhadap sampel nyamuk serta adanya faktor eksternal seperti suhu, kelembaban dan angin dimana faktor eksternal tersebut dikendalikan dalam laboratorium.

Cara kerja racun sampai menimbulkan suatu efek terhadap hewan coba memerlukan suatu proses mulai dari ekspose racun terhadap hewan coba, distribusi racun dalam tubuh hewan sampai mencapai target organ, metabolism racun dalam tubuh hewan sampai proses ekskresi racun dari tubuh hewan coba [10]. Proses eksposure racun adalah paparan hewan terhadap racun yang dapat terjadi melalui kontak kulit untuk racun kontak, melalui oral lewat makanan minuman untuk racun lambung, melalui pernapasan untuk racun pernapasan dan melalui perantara tumbuhan untuk racun yang bersifat sistemik. Sifat racun berdasarkan port de entry ini sangat penting diketahui sebagai dasar pemberian dan aplikasi sehingga racun dapat bekerja secara efektif dan efisien.[10].

Insektisida golongan organophosphate adalah racun kontak, artinya port de entry dari racun jenis ini adalah bisa melalui kontak langsung dengan kulit. Insektisida golongan racun kontak sangat bagus digunakan untuk hama atau hewan yang mobil dari satu tempat ke tempat lain dengan cara terbang seperti belalang, nyamuk, dan serangga. Cara penggunaan atau aplikasi racun yang bersifat kontak ini harus menyesuaikan target sasaran, apabila hewan sasaran berhabitat di air seperti larva, maka dapat diberikan sebagai larvasida dalam bentuk granula. Untuk hewan sasaran yang bias terbang seperti nyamuk pada stadium dewasa maka dapat diberikan dalam bentuk spray seperti fogging baik cold fogging maupun thermal fogging [7]. 
Acetylcholin atau asetilkolin merupakan salah satu neurotransmitter (zat penghantar rangsangan saraf) yang mentransmisikan sinyal atau rangsangan yang diterima untuk diteruskan diantara sel-sel saraf yang berdekatan atau pada sambungan antara ujung akhir saraf dan otot atau neuro-muscular junction. Acetylcholine yang merupakan neurotransmitter yang terdapat pada sistem saraf pusat maupun sistem saraf tepi disintesis di ujung presinaps dari acetyl co-A dan choline dengan bantuan enzim choline acetyltransferase. Saat ada impuls listrik dari ujung saraf maka acetylcholine segera terbentuk dan gelembung acetylcholine ini bergerak kearah sinaps dengan membawa impuls listrik untuk diteruskan ke saraf yang lain atau ke otot. Acetylcholine yang membawa impuls saraf akan segera dipecah kembali untuk didaur ulang dengan bantuan enzim cholinesterase menjadi acetyl co-A dan choline untuk dibawa ke ujung saraf kembali dan dipergunakan untuk produksi acetylcholine yang baru [10].

Pemecahan acetylcholine menjadi acetyl co-A dan cholin agar dapat didaur ulang di celah sinaps memerlukan bantuan enzim cholinesterase. Enzim cholinesterase akan terganggu kerjanya apabila terdapat zat-zat yang dapat menghambat kerja enzim cholinesterase itu sendiri. Cholinesterase adalah enzim yang memecah acetylcholine dengan cara menghidrolisis acetylcholine menjadi acetyl coA dan choline. Jika aktifitas enzim cholinesterase yang ada pada celah sianps dan neuro-muscular junction menurun, maka akan mengakibatkan aktifitas acetylcholine akan terus berlangsung dan terjadi kontraksi otot yang terus-menerus [9]. Aktifitas otot yang terus -menerus berkontraksi ini terjadi pada semua otot termasuk otot-otot pernapasan sehingga akan menyebabkan terganggunya sistem pernapasan yang berakhir dengan kelelahan otot atau fatique dan otot tidak mampu lagi untuk melakukan aktifitas depolarisasi dan repolarisasi yang berakibat terhentinya suplai oksigen keseluruh tubuh [9].

Hasil penelitian ini sejalan dengan penelitian sebelumnya tentang serai wangi yang dilakukan oleh Sukamto didapatkan bahwa kandungan senyawa metabolit sekunder pada ekstrak kasar dengan menggunakan pelarut metanol dan fraksi etil asetat dari batang serai wangi (Cymbopogon nardus) adalah flavonoid, fenolik dan terpenoid, sedangkan dengan menggunakan fraksi etil asetat hanya mengandung senyawa steroid [13]. Penelitian yang dilakukan oleh Niluh Arcani menyatakan bahwa dalam mengurangi larva demam berdarah maka dilakukan dengan pemanfaatan ekstrak serai wangi [12]. Dari penelitian tersebut didapatkan semua konsentrasi pada kelompok perlakuan memiliki hasil perbedaan secara bermakna dengan kelompok kontrol dengan nilai $\mathrm{p}<0,05$. Jumlah kematian larva tertinggi pada konsentrasi $2 \%$ yaitu $38 \%$ kematian larva dan terendah pada konsentrasi $0,05 \%$ dan konsentrasi $0,1 \%$ yaitu $8 \%$ kematian larva. Disimpulkan bahwa semua konsentrasi pada kelompok perlakuan efektif sebagai larvasida apabila dibandingkan dengan kontrol dengan nilai $\mathrm{p}<0,05$ [12].

\section{Kesimpulan}

Hasil uji statistic Repeated Measure GLM pada penelitian ini memberi bukti bahwa terdapat pengaruh yang signifikan antara variabel konsentrasi ekstrak batang serai wangi dan waktu observasi (time effect) dalam bentuk spray sebagai bioinsektisida terhadap jumlah kematian sampel nyamuk Aedes aegypti. Variabel konsentrasi secara signifikan mempengaruhi jumlah kematian sampel nyamuk dengan LC50 sebesar 3.198 ppm. Variabel time effect secara signifikan mempengaruhi jumlah kematian sampel nyamuk dengan nilai LT50 sebesar 27,49 menit setelah intervensi.

\section{Referensi}

[1] Prasetyowati, H \& Hendri,J. (2016) Status Resistensi Aedes aegypti (Linn.) Terhadap Organofosfat di Tiga Kotamadya DKI Jakarta. Jurnal. Pangandaran : Loka Litbang P2B2 Ciamis.

[2] Mahyuni,EL. (2014) Faktor Resiko Dalam Penggunaan Pestisida Terhadap Keluhan Kesehatan Petani di Kecamatan Berastagi Kabupaten Karo 2014. Jurnal Kesmas 9 (1): 79-89. Medan : Fakultas Kesehatan Masyarakat Universitas Sumatera Utara.

[3] Johan,P.R. (2016) Profil Kesehatan Indonesia. Katalog Dalam Terbitan. Jakarta: Kemenkes RI.

[4] Perumalsam, H. (2017) Larvacidal Activity of Compounds Isolated from Asarum heterotrophoides Againts Culex pipiens pallens, Aedes aegypti, and Ochlerotatus togoi. Jurnal of Medicine Entomology. Seoul : Seoul National University.

[5] Atta, JP \& Mannolo, MMQ. (2014) In Vitro Evaluation of Cymbopogon nardus Essential Oil Against Leaf Disease Fungus of Narra (Pterocarpus indicus Wild). Int.Res.J.Biological Sci. 3 (8): 56-59. College Laguna : University of the Philippines Los Banos.

[6] Notoatmodjo,S. (2012) Metodologi Penelitian Kesehatan. KDT. Jakarta : Rineka Cipta.

[7] Verawati, A. Dkk. (2013) Identifikasi Kandungan Kimia Ekstrak Etanol Serai Bumbu (Cymbopogon citratus D.C) dan Uji Efektifitas Repelen Terhadap Nyamuk Aedes aegypti. Jurnal Sains dan Matematika. 21 (1): 20-24. Semarang : Universitas Diponegoro.

[8] Daniel, Cong, dkk. (2015) Optimal Extraction and Evaluation on The Oil Content of Citronella Oil Extracted from Cymbopogon nardus. Malaysia. The Malysian Journal of Ananlytical Sciences.

[9] Victor, Rodwell, dkk. (2008) Biokimia Harpe Edisi 30. Jakarta. Penerbit Buku Kedokteran, EGC.

[10] Ernest, Hodgson. (2011) A Texbook of Modern Toxicology Fourt Edition. North Carolina University. John Willey@ Son.

[11] Majawati, EL. (2015) Kerentanan Vektor Demam Berdarah Dengue Terhadap Insektisida Golongan Organophospat. Jurnal . Jakarta : Bagian Parasitologi Ukrida.

[12] Niluh, Arcani, dkk. (2017) Efektifitas Ekstrak Etanol Serai Wangi (Cymbopogon nardus) sebagai Larvasida Aedes aegypti. Denpasar. EJurnal Medika Udayana.

[13] Sukamto dan Suheryadi. (2011) Serai Wangi () sebagai Penghasil Minyak Atsiri, Tanaman Konservasi dan Pakan Ternak. Bogor. Posiding Seminar Nasional. 